\title{
IjEHSR
}

Original Article

The psychological impact of COVID-19

lockdown on medical student's education.

Subata Siddiqui ${ }^{(\mathbb{D})}$, Atif Hafeez Siddiqui $(\mathbb{D})$, Sumaiya Jafri $\left.{ }^{(}\right)$

Amjad Siraj Memon

Dow University of Health Sciences, Karachi-Pakistan.

OPEN ACCESS
Doi: 10.29052/IJEHSR.v9.i1.2021.35-41

Corresponding Author Email:

subatasiddiqui@gmail.com

Received 16/11/2020

Accepted 08/01/2021

First Published 01/03/2021

\section{(c) (C)}

(C) The Author(s). 2021 Open Access This article is distributed under the terms of the Creative Commons Attribution 4.0 International License (http://creativecommons.org/licenses/by/4.0/)

\section{Abstract}

Background: The Coronavirus Disease 2019 (COVID-19) lockdown has severely affected all aspects of life, including medical students. The present study was designed to gain perspective on how the COVID-19 lockdown has affected Karachi's medical student's study patterns and mental health.

Methodology: Undergraduate students from twelve medical colleges participated in this cross-sectional survey. A self-administered online survey form was sent to 1000 medical students via WhatsApp and other social media platforms. A total of 670 responses were received. Questions regarding the psychological impact of lockdown and wellbeing concerns about the future during lockdown were part of this survey. The Hamilton Anxiety Rating Scale was used to determine the level of anxiety in students.

Results: According to our survey, 270 (40.8\%) medical students who participated in the survey have been severely affected, where 392 students (60.1\%) either did not study daily or spent less than 2 hours studying on average. This situation has also taken a severe toll on their mental health as 314 (47.4\%) students proved to have anxiety, a feeling of irritation and uneasiness most of the time during the day. Many students, 439 (66.3\%), also faced difficulty concentrating while doing menial tasks or studying.

Conclusion: Most students faced a severe loss of study and showed anxiety and depression symptoms during the lockdown period.

\section{Keywords}

COVID-19, Lockdown, Medical Education, Psychological Impact, Online Teaching. 


\section{Introduction}

In March 2020, the World Health Organization (WHO) declared the COVID-19 outbreak a pandemic as, by then, about 114 countries were affected ${ }^{1}$. Moreover, to control the enormous death toll due to this virus, the $\mathrm{WHO}$ announced that the only way to control this pandemic was social distancing and lock-down ${ }^{2}$. Even though the lockdown resulted in controlling a highly contagious infection, it also has many negative impacts on society, including economic, social, educational, and psychological impacts ${ }^{3-5}$. Pakistan being one of the countries having corona cases, followed the directions of $\mathrm{WHO}$, and a strict lockdown was enforced upon all sectors, including educational institutes. This prolonged lockdown halted educational activities. This created a high level of anxiety among the students due to educational loss and the potentially fatal disease. The medical students were no exception ${ }^{6}$. To our knowledge, no study has yet been conducted to evaluate Pakistani medical students' educational and psychological impact; therefore, this study was conducted to interrogate the aforementioned issues.

Karachi's medical colleges have started online theory classes and have detailed and interactive sessions with the students. However, even though enhanced educational activities may prove helpful in minimizing psychological stress and educational loss ${ }^{7,8}$. Medical education is one of the most challenging studies. It demands continuation and regularity in theoretical teaching and hands-on training and practical knowledge, especially in clinical teachings, which cannot be provided by online classes only. Also, since we have an integrated modular system in most medical colleges, the clinical aspects have a significant role in basic medical studies ${ }^{9}$. The students of all years are affected by the loss of practical labs and clinical rotations. The impact of lockdown on education and mental health has been evaluated through this study.

Coronaviruses are a family of viruses that enter the respiratory tract via the nose and cause severe illnesses like the common cold, SARS, and MERS. In 2019, a novel coronavirus was identified as the cause of a severely contagious disease outbreak in Wuhan, China. The newly discovered virus is called the severe acute respiratory syndrome coronavirus-2 (SARS-CoV-2) $)^{1}$. The disease it causes is called COVID-19, a worldwide viral disease that has affected millions of people and taken hundreds of thousands of lives to date.

\section{Methodology}

Twelve medical college undergraduate students participated in this cross-sectional survey. Students of both genders were selected from 1st year to final year. A self-administered questionnaire was prepared using the google forms system, and a link was sent to 1000 students randomly via WhatsApp and other social media platforms. A total of 670 students participated in the survey. Students were asked to fill the questionnaire voluntarily in a time frame of 3 months. Confidentiality of the study was maintained throughout the study.

The demographics section included questions related to age, gender, and year in medical college. Simultaneously, various questions regarding the psychological impact of lockdown and wellbeing concerns about the future during lockdown were part of this survey. The Hamilton Anxiety Rating Scale was used to determine the level of anxiety in students. The data was analyzed using SPSS version 22.0. The findings are expressed in the form of total number and percentage.

\section{Results}

A total of 662 responses were received, which were predominantly from female medical students (73.6\%). The respondents were from all school years, mostly from $3^{\text {rd }}$ year (27.3\%), and their ages varied from 18 to 25 years. Out of all, 391 (59\%) were of this opinion that Coronavirus is an acute disease, while only 66 (10\%) students believed it is a mild to moderate disease. When asked about COVID-19 preventions, 458 (69.2\%) thought that the best method to prevent the coronavirus spread is social distancing (Table 1). 


\begin{tabular}{|c|c|c|}
\hline Variables & & $n(\%)$ \\
\hline Age; years (Mean $\pm S D)$ & & $20.6 \pm 1.6$ \\
\hline \multirow[t]{2}{*}{ Gender } & Male & $175(26.4)$ \\
\hline & Female & 487(73.6) \\
\hline \multirow[t]{5}{*}{ Year in Medical School } & 1st & $174(26.3)$ \\
\hline & 2nd & $162(24.5)$ \\
\hline & $3 r d$ & $181(27.3)$ \\
\hline & 4th & $35(5.3)$ \\
\hline & 5th & $110(16.6)$ \\
\hline \multirow{4}{*}{$\begin{array}{l}\text { How severe, in your } \\
\text { opinion, is COVID-19? }\end{array}$} & Mild & $15(2.3)$ \\
\hline & Moderate & $51(7.7)$ \\
\hline & Severe & 205(31.0) \\
\hline & Critical & $391(59)$ \\
\hline \multirow{6}{*}{$\begin{array}{l}\text { Which is the best method of } \\
\text { preventing the spread of } \\
\text { COVID-19? }\end{array}$} & Social distancing & $458(69.2)$ \\
\hline & Lockdown & 141(21.3) \\
\hline & 20 seconds handwashing with soap & $44(6.6)$ \\
\hline & Wearing masks & $14(2.1)$ \\
\hline & Avoiding handshakes & $4(0.6)$ \\
\hline & Use of sanitizer & $1(0.2)$ \\
\hline
\end{tabular}

\section{Effect on student's education}

When inquired about the impact of COVID-19 lockdown on medical students' education, 270 (40.8\%) of the students were $100 \%$ affected, while only 30 (4.5\%) students suggested no impact of lockdown in their studies. When asked about their productivity in studies compared to the pre-COVID era, only $18.58 \%$ said they were more productive while staying home during the lockdown period.

Table 2: Students' responses to the consequence of lockdown on studies

\begin{tabular}{|c|c|c|}
\hline Variable & & $n(\%)$ \\
\hline \multirow[t]{5}{*}{ Impact of lockdown on studies } & Extremely & $270(40.79)$ \\
\hline & Severely & 183(27.64) \\
\hline & Moderately & 133(20.09) \\
\hline & Slightly & $46(6.95)$ \\
\hline & Not at all & $30(4.53)$ \\
\hline \multirow[t]{3}{*}{ Productivity in studies during the lockdown period } & Yes & $123(18.58)$ \\
\hline & No & $402(60.73)$ \\
\hline & May be & 137(20.69) \\
\hline \multirow[t]{6}{*}{ Average time spent on studies during the lockdown } & $>8$ hours & 16(2.42) \\
\hline & 6 to 8 hours & 16(2.42) \\
\hline & 4 to 6 hours & $65(9.82)$ \\
\hline & 2 to 4 hours & 168(25.38) \\
\hline & $<2$ hours & 283(42.75) \\
\hline & Not at all & 115(17.37) \\
\hline
\end{tabular}

When asked about the average time spent on studies during the lockdown, a majority of 392 (60.1\%) either did not study or spent less than 2 hours on average. Most students, 322 out of 662 (48.6\%), preferred to study from course textbooks, 250 students (37.8\%) prefer watching online lectures or videos. 
Of the remaining students, 60 (9.1\%) prefer online classes, 21 students (3.2\%) use previous lecture slides, while only nine students (1.4\%) prefer reference sites as their mode of study. When asked about how much of the syllabus the students can cover independently, the majority, i.e. 226 students (34.1\%), responded they could manage to cover 50 to $7 \%$ of the entire syllabus. 175 (26.4\%) students also claim they can complete 75 to $100 \%$ of the syllabus independently. 152 (23\%) students think they can cover 25 to 50\%, while 109 (16.5\%) students think they can only cover 0 to $25 \%$ syllabus by themselves.

A major setback of this lockdown on medical students seems to be the halted clinical exposure.
When asked how the students attempt to compensate for it, 454 students (68.6\%) answered that they do not do anything about it. One hundred students $(15.1 \%)$ watch online videos of clinical/surgical procedures; 64 students (9.7\%) are taking help from online classes. In comparison, 42 students (6.3\%) claimed they read online articles. Two students $(0.3 \%)$ also said they watched Grand Round Tutorials online.

\section{Psychological effects on medical students}

Since the COVID-19 lockdown is far from usual, it has had many adverse psychological effects on medical students. A list of phrases was provided that describe feelings that students may or may not face in Table 3.

Table 3: Responses regarding the psychological impact of lockdown on medical students

\begin{tabular}{|c|c|c|c|}
\hline Questions & $\begin{array}{l}\text { Not at all } \\
\text { n(\%) }\end{array}$ & $\begin{array}{l}\text { Rarely } \\
\text { n(\%) }\end{array}$ & $\begin{array}{l}\text { Mostly } \\
\mathrm{n}(\%)\end{array}$ \\
\hline $\begin{array}{l}\text { How often have you been facing problems like becoming } \\
\text { irritated or annoyed quickly? }\end{array}$ & $115(17.4)$ & $233(35.2)$ & $314(47.4)$ \\
\hline $\begin{array}{l}\text { How often have you been facing the fear that something } \\
\text { terrible would happen? }\end{array}$ & 128(19.3) & 274(41.4) & 260(39.3) \\
\hline How often have you been facing difficulty in concentrating? & $88(13.3)$ & 135(20.4) & $439(66.3)$ \\
\hline How often have you been feeling anxious or on edge? & 131(19.8) & 258(39.0) & $273(41.2)$ \\
\hline $\begin{array}{l}\text { How often have you been facing issues like a lack of interest in } \\
\text { hobbies and activities? }\end{array}$ & $173(26.1)$ & $180(27.2)$ & $309(46.7)$ \\
\hline How often have you been feeling tensed and fatigued? & 153(23.1) & 214(32.3) & 295(44.6\%) \\
\hline $\begin{array}{l}\text { How often have you been worrying too much about different } \\
\text { things? }\end{array}$ & 143(21.6) & 206(31.1) & $313(47.3)$ \\
\hline How often have you been feeling restless (fidgeting/pacing)? & 185(27.9) & 215(32.5) & 262(39.6) \\
\hline How often have you been facing the problem of insomnia? & 271(40.9) & $180(27.2)$ & 211(31.9) \\
\hline
\end{tabular}

In this survey, the students were asked about their future wellbeing concerns, and their responses were noted. A total of 167 (25.2\%) worried about their family's health as an individual, followed by their studies 96 (14.5\%), then about social isolation 39 (5.9\%) and delayed exams 31 (4.7\%). Details of concerns related to tabulation are given in Table 4.

Table 4: Student concerns about various aspects of well being

\begin{tabular}{lcccc}
\hline Questions & $\begin{array}{c}\text { Not at all } \\
\mathbf{n}(\%)\end{array}$ & $\begin{array}{c}\text { Slightly } \\
\text { worried } \\
\mathbf{n}(\%)\end{array}$ & $\begin{array}{c}\text { Moderately } \\
\text { Worried } \\
\mathbf{n}(\%)\end{array}$ & $\begin{array}{c}\text { Extremely } \\
\text { worried } \\
\mathbf{n ( \% )}\end{array}$ \\
\hline $\begin{array}{l}\text { Rate according to your worries about the } \\
\text { community }\end{array}$ & $28(4.2)$ & $85(12.8)$ & $404(61.0)$ & $145(21.9)$ \\
\hline
\end{tabular}




\begin{tabular}{|c|c|c|c|c|}
\hline $\begin{array}{l}\text { Rate according to your worries about the } \\
\text { capacity of the healthcare system in } \\
\text { Pakistan }\end{array}$ & $45(6.8)$ & $76(11.5)$ & $350(52.9)$ & 147(28.9) \\
\hline $\begin{array}{l}\text { Rate according to your worries about the } \\
\text { safety of healthcare professionals }\end{array}$ & $43(6.5)$ & $59(8.9)$ & $329(49.7)$ & $231(34.9)$ \\
\hline $\begin{array}{l}\text { Rate according to your worries about the } \\
\text { national economy }\end{array}$ & $67(10.1)$ & 125(18.9) & $314(47.4)$ & 156(23.6) \\
\hline $\begin{array}{l}\text { Rate according to your worries about the } \\
\text { law and order }\end{array}$ & $79(11.9)$ & $150(22.7)$ & $327(49.4)$ & $106(16.0)$ \\
\hline $\begin{array}{l}\text { Rate according to your worries about the } \\
\text { daily wagers }\end{array}$ & $57(8.6)$ & $57(8.6)$ & $315(47.6)$ & $233(35.2)$ \\
\hline
\end{tabular}

\section{Discussion}

COVID-19 turned the world upside down. Its impact is enormous upon every field of the everyday world. As per the world health organization (WHO), the best way to contain disease spread is a lockdown ${ }^{1}$. Various types of lockdown were implemented in almost all countries affected by COVID-19. Along with social, economic, cultural, and financial impact, the lockdown has grossly disturbed the educational system and put a substantial negative psychological effect upon the public and medical students $^{4,5}$. The medical undergraduates suffered a significant setback as the routine medical practices and surgeries have been abandoned due to the highly contagious Novel Coronavirus. The regular outpatient departments at many centers stopped working, and the elective and non-emergency surgeries have been postponed. The intensive care units and a large number of beds were reallocated only for COVID-19 patients ${ }^{10}$. Also, sighting the safety of undergraduate medical students, their clinical rotations have also been suspended.

Our study focused on SARS COV-19 and subsequent lockdown upon medical education and psyche of medical students. Since it is a new disease hence very little literature is available on these dimensions of COVID -19 .

Medical education is different as it is not only related to books, lectures, and tutorials, but it needs much physical interaction with patients \& their attendants. Practical or hands-on training cannot be achieved when following the standardized rules of social distancing. Hanad A. also highlighted the problems that the students are facing due to Covid 19 consequent lockdown ${ }^{11}$. Although there is an emerging trend of online teaching, it does not fulfill the requirement of barely sufficient or minimal practical teaching. Therefore, we think that medical education is worst affected by the lockdown due to Covid $19 \&$ the medical students are also victims of psychological disturbances during lockdown ${ }^{12}$. We generated a Google form for collecting data from medical students at different medical colleges of Karachi, to be filled by themselves \& study the different aspects of how this lockdown influences their education \& altered their attitudes \& behaviours. Analysis of most of the questions is depicted in tables. Overall, the survey gives the impression that most students feel that they suffered a significant educational \& training deficit.

In our study, $68.4 \%$ of students believe that their studies are severely affected due to lockdown. A reduction in productivity in studies was confessed by $60.7 \%$ of students. Students' time in studies was less than 2 hours in the case of $60 \%$ of students, and if it is taken to 4 hours or less daily, then the figure swells up to $75.5 \%$. It is to note that this is usually considered a very meagre time dedicated to studies by a medical student in regular college days. Most of the students, i.e. $48.6 \%$, preferred to study textbooks, while prerecorded lectures and videos, are being watched by $37.8 \%$. Notably, the online classes were not popular, and only $9.1 \%$ of students were taking the lectures seriously. Alexander et al, in their article, discuss the challenges and disadvantages of online classes and assessment, especially in fields that require 
practical training ${ }^{12}$. Their article also discusses the challenges of deficient infrastructure, resources, and technical support to run online courses by many universities. According to our survey, clinical exposure was halted totally for $72 \%$ of clinical students. At the same time, only $16.9 \%$ continued to link themselves with clinical work through youtube videos. In her article, Suzanne Rose also indicated the threat of stagnation of the learning process achieved through clinical sub-internship, clinical postings, and other clinical research projects due to closure of educational institutes, resulting in loss of clinical environment ${ }^{13}$. The same is endorsed by Goh \& Sandars in their article as well ${ }^{14}$.

Our study also covers the psychological aspects of individual medical students. Since medical students are also part of the community, their anxiety was not limited to their education and studies. Mostly the participants were worried about the health of family members as well as about the community health. They showed their concerns about incapacitating the health care system, the safety of health care professionals, the national economy, and the law and order situation that may emerge due to lockdown. This is also discussed in several other articles. Roy et al. from India has found that a large chunk of the educated population, included in her study, was worried about contracting infections and their close relatives' health. They reported $28 \%$ of participants with difficulty sleeping ${ }^{15}$. Similarly, from turkey, Torun and colleagues also concluded in their article that "medical students were highly worried about being infected with COVID-19," and the sleep patterns of $29.5 \%$ of students changed after COVID-19 pandemic ${ }^{16}$, which are relatively close to ours, i.e. $32 \%$.

Pfefferbaum \& North, in their article, discussed the increased emotional distress and psychiatric deviation from usual attitude due to Covid 19 pandemic and lockdown ${ }^{17}$. Similarly, Brooks et al. explained the higher chances of acute stress disorder among quarantined health care workers ${ }^{18}$. They also stated in their review that the "psychological impact of quarantine is wide- ranging, substantial, and can be long lasting." Alexander et al, describe an impactful level of stress and uncertainty among university students due to lockdown ${ }^{12}$. He claimed interruption in regular teaching, postponement of exams, and graduation delay to be a primary reason for stress.

On the other hand, Lasheras et al, in their study, say that the anxiety levels in medical students did not increase during the COVID-19 outbreak ${ }^{19}$. In contrast, were surprisingly lower than the usual everyday circumstances due to decreased academic stress and broader or earlier knowledge of the virus, which is not quite in line with our findings. No specific study is yet available that highlights the educational and psychological problems of medical students. However, having certain limitations in our study, it is still very beneficial. It will throw sufficient light on what the medical students are going through during this pandemic and resulting lockdown.

\section{Conclusion}

In conclusion, the studies, learning process, and clinical or practical training of medical students have been badly hampered. Although many medical universities and colleges have vigorously adopted online teaching, it does not replace the more familiar face to face teaching experience. It is not an alternative to practical and hands-on training. We also conclude that medical students are significantly sensitized and are under immense stress due to Covid 19 pandemic and subsequent lockdown resulting in anxiety, irritability, and fearfulness. They were found to have difficulty concentrating on their studies \& lost interest in their hobbies \& other extra-curricular activities. Much reported a lack of good peaceful sleep. We hypothesize that this could be due to the fact that medical students being well aware of the gravity \& possible adversities linked with the notorious Coronavirus, are more sensitive \& have feared not only about the health of their near \& dear ones but also for the general public, the safety of healthcare professionals, fragile healthcare system \& limited resources. They were also worried about the national economy, daily wagers' income \& threatened law \& order integrity because of 
lockdown. There is a scope for other studies, such as comparing educational \& psychological disturbances between medical undergraduates \& those who belong to other disciplines.

\section{Conflicts of Interest}

None.

\section{Acknowledgement}

The authors wish to acknowledge the Medical Affairs department of Getz Pharma for helping in statistical assistance and manuscript formatting.

\section{Funding}

None.

\section{References}

1. World Health Organization. Coronavirus Disease (COVID-19) Pandemic. (Updated: March, 2020). Available

at: https://www.who.int/emergencies/diseases/nov el-coronavirus-2019

2. Lau H, Khosrawipour V, Kocbach P, Mikolajczyk A, Schubert J, Bania J, Khosrawipour T. The positive impact of lockdown in Wuhan on containing the COVID-19 outbreak in China. J. Travel Med. 2020;27(3): taaa037.

3. Wang C, Pan R, Wan X, Tan Y, Xu L, Ho CS, Ho RC. Immediate psychological responses and associated factors during the initial stage of the 2019 coronavirus disease (COVID-19) epidemic among the general population in China. Int. J. Environ. Res. Public Health. 2020;17(5):1729.

4. Hawryluck L, Gold WL, Robinson S, Pogorski S, Galea S, Styra R. SARS control and psychological effects of quarantine, Toronto, Canada. Emerg. Infect. Dis. 2004;10(7):1206.

5. Khan S, Saleem Y, Aziz S. Psychological Response \& Perceived Risk Associated with Coronavirus Disease. APP. 2020;7:9-18.

6. Salman M, Asif N, Mustafa ZU, Khan TM, Shehzadi $\mathrm{N}$, Hussain K, Tahir H, Raza MH, Khan MT. Psychological Impact of COVID-19 on Pakistani University Students and How They Are Coping. MedRxiv. 2020 June 3.

7. Reynolds DL, Garay JR, Deamond SL, Moran MK, Gold W, Styra R. Understanding, compliance and psychological impact of the SARS quarantine experience. Epidemiol. Infect. 2008;136(7):997-1007.
8. Ahmed S. The chaos of healing: Risking mental health amid COVID-19 in Pakistan. APP. 2020;7:6-8.

9. Quintero GA, Vergel J, Arredondo M, Ariza MC, Gómez P, Pinzon-Barrios AM. Integrated medical curriculum: advantages and disadvantages. Journal of medical education and curricular development. 2016;3:JMECD-S18920.

10. Spinelli A, Pellino G. COVID-19 pandemic: perspectives on an unfolding crisis. $\mathrm{Br} J$ Surg. 2020;107(7):785-787.

11. Ahmed H, Allaf M, Elghazaly H. COVID-19 and medical education. Lancet Infect Dis. 2020;20(7):777-778.

12. Alexander M, John RA, Sahu P. Closure of universities due to Coronavirus Disease 2019 (COVID-19): impact on education and mental health of students and academic staff. Cureus. 2020;12(4): e7541.

13. Rose S. Medical student education in the time of COVID-19. Jama. 2020;323(21):2131-2132.

14. Goh PS, Sandars J. A vision of the use of technology in medical education after the COVID-19 pandemic. MedEdPublish. 2020 Mar 26;9.

15. Roy D, Tripathy S, Kar SK, Sharma N, Verma SK, Kaushal V. Study of knowledge, attitude, anxiety \& perceived mental healthcare need in the Indian population during COVID-19 pandemic. Asian J Psych. 2020:102083.

16. Torun F, Torun SD. The psychological impact of the COVID-19 pandemic on medical students in Turkey. Pak J Med Sci. 2020;36(6):1355-1359.

17. Pfefferbaum B, North CS. Mental health and the Covid-19 pandemic. N Engl J Med. 2020;383(6):510512.

18. Brooks SK, Webster RK, Smith LE, Woodland L, Wessely S, Greenberg N, Rubin GJ. The psychological impact of quarantine and how to reduce it: rapid review of the evidence. The lancet. 2020;395(10227):912-920.

19. Lasheras I, Garcia PG, Lipnicki D, Notivol JB, Anton RL, de la Camara C, Lobo A, Santabárbara J. Prevalence of Anxiety in Medical Students during the COVID-19 Pandemic: A Rapid Systematic Review with Meta-Analysis. Int. J. Environ. Res. Public Health 2020;17(18):6603. 